\title{
PENGGUNAAN KARTU 'SUPERHERO' UNTUK MENINGKATKAN KEMAMPUAN MEMBACA SISWA KELAS I SLB B YPALB KARANGANYAR
}

\author{
Farida Yuliati \\ SLB B YPALB Karanganyar \\ Farida_421@yahoo.co.id
}

\begin{abstract}
The purpose of this research is to improve the mastery of reading skills for the deaf children grade 1 SLB - B through the use of superhero cards. Subjects of the research are grade 1 SLB - B YPALB Karanganyar. This study uses a classroom action research approach. The techniques of collecting data are through observation, interviews and documentation. The validity of the data uses triangulation. Results of the study are cycle 1, Children's increases in value after reading the card superhero. Prior to the act, the average value of the Traffic reading child, are in the range of 5.33 or $40 \%<P \leq 60 \%$ or sufficient. After the first cycle measures, the average value of children increased to 7.16 or are in the range of $60 \%<P \leq 80 \%$ or better. But there are still children who obtained a value of less than 6 on competence read the word, so it is necessary to act cycle 2. After 2 cycles of action Average - The average value increased to 8 or the child is in the range of $60 \%<P \leq 100 \%$ or higher, and no student who obtained a value of less than 6. In conclusion, the superhero card usage can improve the reading skills of the deaf children SLB-B class I YPALB Karanganyar.
\end{abstract}

Keywords: deaf children, superhero cards, ability to read

\begin{abstract}
Abstrak. Tujuan penelitian ini untuk meningkatan penguasaan kemampuan membaca anak tunarungu kelas 1 SLB - B melalui penggunaan kartu superhero. Subyek penenlitian 3 siswa kelas 1 SLB - B YPALB Karanganyar. Penelitian ini menggunakan pendekatan Penelitian Tindakan Kelas. Teknik pengumpulan data dengan observasi, wawancara dan dokumentasi. Validitas data menggunakan trianggulasi sumber dan metode. Analisis data deskriptif kualitatif. Hasil penelitian siklus 1, Anak mengalami peningkatan nilai setelah dilakukan kegiatan membaca dengan kartu superhero. Sebelum dilakukan tindakan, rata-rata nilai kemapuan membaca anak, 5,33 atau berada pada rentang $40 \%<P \leq 60 \%$ atau cukup. Setelah dilakukan tindakan siklus 1, rata-rata nilai anak meningkat menjadi 7,16 atau berada pada rentang $60 \%<$ $P \leq 80 \%$ atau baik. Namun masih ada anak yang memperoleh nilai kurang dari 6 pada kompetensi membaca kata, sehingga perlu dilakukan tindakan siklus 2. Setelah dilakukan tindakan siklus 2 rata - rata nilai anak meningkat menjadi 8 atau berada pada rentang $60 \%<P \leq 100 \%$ atau tinggi, dan tidak ada siswa yang memperoleh nilai kurang dari 6. Kesimpulan penelitian, penggunaan kartu superhero dapat meningkatkan kemampuan membaca pada anak tunarungu kelas I SLB-B YPALB Karanganyar.
\end{abstract}

Kata Kunci: Anak tunarungu, kartu superhero, kemampuan membaca 


\section{Pendahuluan}

Komunikasi sangat diperlukan dalam bersosialisasi di masyarakat. Komunikasi antar personal dapat dilakukan secara lisan, isyarat maupun tulisan. Untuk dapat berkomunikasi dengan baik diperlukan penguasaan bahasa yang baik pula.

Pengalaman berbahasa atau disebut pemerolehan bahasa, menurut Hastuti (1989:59) adalah bahasa yang diperoleh anak sejak kecil sebagai hasil interaksi dengan lingkungan dengan memenfaatkan pendengarannya. Jika tidak ada hambatan pada fungsi pendengarannya, seorang anak akan segera dapat mengaplikasikan pengalaman berbahasa tersebut dalam interaksinya dengan orang lain. Bagaimana dengan anak yang mengalami hambatan dalam pendengarannya?

Anak tunarungu adalah anak yang mengalami kelainan pada fungsi pendengarannya, baik tuli maupun kurang dengar. Akibat adanya kelainan fungsi pendengaran, anak tunarungu akan mengalami hambatan dalam perkembangan bahasa, bicara dan komunikasinya. Tempat pendidikan untuk anak dengan gangguan pendengaran atau tunarungu tersebut adalah di sekolah khusus untuk anak tunarungu atau SLB-B.

Kebanyakan anak tunarungu ketika masuk sekolah belum bisa diajak berkomunikasi secara verbal. Mereka juga belum bisa melakukan komunikasi secara tertulis. Komunikasi yang biasa dilakukan anak tunarungu adalah bahasa isyarat sederhana.

Adanya disfungsi pendengaran siswa SLB-B di Karanganyar menjadikan pembelajaran bahasa pada mereka mengalami kendala. Sehingga diperlukan strategi tersendiri untuk dapat mengajak mereka belajar membaca.

Selama ini, anak-anak kelas 1 SLB-B YPALB Karanganyar belajar membaca setelah dilakukan percakapan. Dari hasil percakapan akan ditemukan kosa kata baru yang dijadikan master pengembangan bahasa, baik untuk penguasaan perbendaharaan kata baru, latihan bicara, menulis maupun membaca. Dalam latihan membaca, dari kosa kata baru tersebut, pada tahap permulaan anak-anak diajak membaca vocal, suku kata dan pengembangannya. Dari kata 'bando' diambil vokal /a/ dan /o/ yang kemudian dikembangkan /a/,/i/,/u/,/e/ dan /o/. Selanjutnya diambil suku kata/ba/. Sehingga suku kata yang kemudian dikembangkan adalah /ba/, /bi/,bu/,/be/ da /bo/. Kemudian vocal dan suku kata tetrsebut digabungkan sehingga menjadi kata sederhana misalnya : abi, ibu, ubi, dan sebagainya.

Siswa kelas 1 SLB-B YPALB Karanganyar belum lancar membaca. Kebiasaan yang dilakukan anak-anak ini adalah mengalihkan perhatian dengan mengobrol dengan temannya. Mereka sering memperagakan gerakan-gerakan tokoh kartun superhero. Juga menceritakan tokoh kartun super hero yang menjadi idola mereka. Tidak hanya itu, anak-anak juga suka menggunakan kartu bergambar kartun superhero tersebut bermain meskipun sedang belajar sehingga muncul pemikiran bagaimana upaya yang dilakukan guru untuk mengajak siswa kelas 1 belajar membaca melalui kegemaran mereka bermain kartu bergambar kartun super hero tersebut.

Istilah kartu dalam dunia permainan anak dipergunakan untuk menyebut kartu bergambar. Superhero menurut Iqmal, (dalam iqmal.staff.ugm.ac.id/index.php/, diakses 5 Agustus 2011) adalah tokoh rekaan yang dalam ceritanya selalu membasmi kejahatan. Bagian belakang kartu bergambar superhero tersebut seringkali kosong sehingga dapat dipergunakan untuk membuat coretan atau tulisan yang bisa dibaca.

Berdasar pengalaman tersebut muncul rumusan masalah apakah penggunaan kartu superhero dalam pembelajaran bahasa dapat meningkatkan kemampuan membaca siswa kelas 1 SLB-B YPALB Karanganyar?'Dengan hipotehsis tindakan 'Penggunaan kartu superhero dapat meningkatkan kemampuan membaca siswa kelas I SLB-B YPALB 
Karanganyar', penelitian ini bertujuan untuk mengetahui efektifitas penggunaan kartu superhero dalam pembelajaran bahasa untuk meningkatkan kemampuan membaca siswa kelas 1 SLB-B YPALB Karanganyar.

Penelitian ini diharapkan memberi manfaat 1) bagi siwa, membuat siswa senang belajar membaca sehingga kemampuan membaca mereka meningkat. 2) Guru mengetahui strategi pembelajaran bahasa yang efektif, diperoleh media pembelajaran yang cocok untuk dikembangkan dalam kegiatan membaca. 3) bagi sekolah, dapat meningkatkan hasil pembelajaran bahasa, tumbuhnya motivasi dan kreatifitas pada guru dalam mengembangkan kegiatan pembelajaran bahasa, dan dapat digunakan sebagai acuan bagi guru lain dalam melaksanakan srategi pembelajaran bahasa untuk siswa.

\section{Metode Penelitian}

Penelitian yang dilakukan di SLB B YPALB Karanganyar ini merupakan penelitian tindakan kelas. Subyek penelitian 3 siswa kelas I yang mengalami kesulitan dalam membaca. Sumber data diperoleh dari observasi, wawancara dan dokumentasi. Validitas data dilakukan dengan teknik trianggulasi. Teknik analisis data yang digunakan adalah deskriptif komparatif, artinya setelah dilakukan tindakan, dilakukan pengamatan dan tes terhadap kemampuan anak. Lalu dilakukan analisis data secara deskriptif komparatif untuk pembuatan rancangan siklus berikutnya dan membandingkan hasil awal dengan hasil dari siklus berikutnya.

Keberhasilan penelitian ini dilihat dari adanya peningkatan kemampuan membaca pada siswa kelas 1 SLB-B YPALB Karanganyar yang mengalami kesulitan membaca. idikator keberhasilannya mengacu pada kriteria sebagai berikut. Jika rata-rata nilai anak $80 \%<\mathrm{P} \leq 100 \%=$ Sangat tinggi, $60 \%<\mathrm{P} \leq 80 \%=$ Tinggi, $40 \%<\mathrm{P} \leq 60 \%$ $=$ Cukup, $20 \%<\mathrm{P} \leq 40 \%=$ Rendah dan $0 \%$ $<\mathrm{P} \leq 20 \%=$ Sangat rendah. Indikator yang ditetapkan adalah $60 \%<\mathrm{P} \leq 80 \%=$ Tinggi.

Penelitian tindakan ini menggunakan model yang dilakukan Kemmis dan Mc Taggart yang merupakan pengembangan dari Model Kurt Lewin. Dengan empat komponen, yaitu perencanaan atau planning, tindakan atau acting, pengamatan atau observing, dan refleksi atau reflecting.

\section{Hasil Penelitian Dan Pembahasan}

\section{A. Diskripsi Kondisi Awal}

Siswa kelas I SLB-B YPALB

Karanganyar, berdasarkan hasil pengamatan, anak - anak belum bisa membaca. Kemampuan Membaca Siswa Kelas I SLB-B YPALB Karanganyar masih rendah. Hasil observasi sebelum tindakkan dilakukan pada siswa kelas I SLB-B YPALB Karanganyar untuk tahun pelajaran 2014/2015, dapat dilihat pada tabel aktifitas siswa di bawah ini.

Tabel 1. Hasil pengamatan aktifitas siswa dalam membaca

\begin{tabular}{|c|c|c|}
\hline No & Variabel aktifitas anak & Penilaian \\
\hline 1 & Aktifitas anak dalam mengucapkan/ membaca vokal & Dapat membaca vokal \\
\hline 2 & Membaca suku kata & Sering salah mengucapkan \\
\hline 3 & $\begin{array}{l}\text { Membaca kata sederhana yang merupakan gabungan } \\
\text { vokal dan satu suku kata }\end{array}$ & $\begin{array}{l}\text { Anak dapat membaca vokal pada } \\
\text { awal kata dengan baik, tetapi suku } \\
\text { kata belum dapat dibaca dengan } \\
\text { baik. }\end{array}$ \\
\hline 4 & Membaca kata sederhana dari dua suku kata & $\begin{array}{l}\text { Belum lancar membaca kata seder- } \\
\text { hana dari dua suku kata. }\end{array}$ \\
\hline 5 & Membaca kalimat sederhana & $\begin{array}{l}\text { Belum berhasil membaca kalimat } \\
\text { sederhana dengan lancar }\end{array}$ \\
\hline 6 & Nilai evaluasi membaca & Belum tuntas semua \\
\hline
\end{tabular}


Nilai pengamatan kemampuan membaca yang masih rendah. Hal ini dapat dilihat pada tabel nilai pre tes berikut.

Tabel 2. Nilai anak dari hasil pengamatan awal

\begin{tabular}{cccc}
\hline No. & Nama Anak & Nilai & Keterangan \\
\hline 1. & PW & 5 & Belum tuntas \\
2. & FAR & 7 & Tuntas \\
3. & SDP & 4 & Belum tuntas \\
& Jumlah Nilai & 16 & \\
& Rata - rata & 5,33 & Belum tuntas \\
\hline
\end{tabular}

\section{B. Siklus I}

1. Perencanaan

Tindakan direncakan akan dilakukan sebanyak 4 kali pertemuan pada pertengahan bulan Sepetember ( tanggal 15 sampai dengan 18 September 2014). Dilanjutkan evaluasi siklus I pada tanggal 19 September 2014. Setelah evaluasi langsung dilakukan refleksi dan perencanaan siklus II. Rencana pmbelajaran yang akan dilakukan pada siklus I adalah membaca kata sederhana. Kegiatan akandiawalidenganmembaca(mengucapkan) vokal lalu membaca suku kata. Dari masingmasing pertemuan dikembangkan kata yang merupakan gabungan vokal dan suku kata. Lalu dikembangkan menjadi kata sederhana yang merupakan gabungan dua suku kata.

\section{Pelaksanaan}

\section{a) Persiapan}

Tahap persiapan dilakukan guru untuk mengatur tempat duduk $1 / 2$ lingkaran. Mengajak anak untuk berdoa bersama. Mengabsen sambil mengamati kesiapan anak dalam belajar. Melakukan percakapan dan menyiapkan gambar superhero yang sudah digunting.

\section{b) Kegiatan Pembelajaran}

Setelah dilakukan percakapan, guru mengambil kata yang menjadi topik percakapan. Menuliskan kata tersebut di papan tulis, lalu mengajak anak melakukan identifiasi. Selanjutnya guru menulis vokal atau suku kata yang diidentifikasi pada punggung (sebalik) kartu superhero. Pertemuan pertama siklus I, siswa membaca vokal (/a/,/i/,/u/,/e/,/o/). dilanjutkan membaca suku kata /ba/,/bi/,/bu/,/be/,/bo/ dari kartu. Selanjutnya dua kartu disatukan sehingga membentuk kata sederhana, Kata sederhana yang dibaca anak pada pertemuan pertama adalah : ibu, abi, iba, ubi, abu, babi, bibi, babe, bobi, bebi. Setelah membaca, anak diminta diminta menuliskannya di papan tulis. Setelah kata yang dibaca ditulis di papan tulis, dan membaca ulang dan mengajak temannya membaca.

Pertemuan ke dua, setelah membaca vokal dan suku kata /ba/,/bi/,/bu/,/be/,/ bo/, membaca suku kata /pa/,/pi/,/pu/,/ pe/,/po/ dari kartu. Kata sederhana yang dibaca anak pada pertemuan ke dua adalah : ibu, ebi, api, ipa, opa, bapa, papa, papi, pipa, popi. Pertemuan ke tiga $/ \mathrm{ma} /, / \mathrm{mi} /, / \mathrm{mu} /, / \mathrm{me} /, / \mathrm{mo} /$ dengan kata sederhana ami, umi, ima, ema, oma, bima, bumi, mama, mami, mumi. Pertemuan ke empat, /la/,/li/,/lu/,/le/,/ lo/, dengan sederhana ali, uli, ila, oli, eli, bumi, puma, lima, lupa, lama.

\section{c) Evaluasi}

Evaluasi dilakukan dengan meminta anak membaca kata sederhana dari kartu yang ditunjukkan guru. Pada saat evaluasi, guru melakukan pengamatan terhadap kemampuan anak dalam membaca dan membubuhkan cantangan pada lembar pengamatan yang sudah dipersiapkan oleh guru.

\section{d) Hasil Pengamatan}

Hasil pengamatan dari tindakan yang dilakukan pada siklus I. Anak merasa senang karena, setelah berhasil membaca, siswa diperbolehkan melihat gambar superhero-nya. Kemampuan membaca vokal, suku kata dan kata pada PW sebesar $70 \%$. Sedangkan pada FAR $85 \%$ dan pada SDP $60 \%$. Indikator keberhasilan kegiatan siswa selama proses pembelajaran siklus 1 dapat dilihat pada tabel berikut. 
Tabel 3. Hasil ketrampilan membaca setelah siklus 1

\begin{tabular}{|c|c|c|c|c|c|c|c|c|}
\hline \multirow{2}{*}{ No } & \multirow{2}{*}{$\begin{array}{c}\text { Variabel } \\
\text { Tindakan }\end{array}$} & \multirow{2}{*}{$\begin{array}{l}\text { Indikator yang } \\
\text { Ditetapkan }\end{array}$} & \multicolumn{3}{|c|}{$\begin{array}{c}\text { Penilaian aktifitas } \\
\text { siswa }\end{array}$} & \multicolumn{3}{|c|}{ Prosentase (\%) } \\
\hline & & & PW & FAR & SDP & PW & FAR & SDP \\
\hline 1 & $\begin{array}{l}\text { Aktifitas anak dalam } \\
\text { mengucap-kan/memba- } \\
\text { ca vokal (5) }\end{array}$ & $60 \%<\mathrm{P} \leq 100 \%$ & 4 & 5 & 3 & 80 & 100 & 60 \\
\hline 2 & $\begin{array}{l}\text { Membaca suku kata } \\
(20)\end{array}$ & $60 \%<\mathrm{P} \leq 100 \%$ & 14 & 18 & 14 & 70 & 90 & 70 \\
\hline 3 & $\begin{array}{l}\text { Membaca kata seder- } \\
\text { hana yang merupakan } \\
\text { gabungan vokal dan } \\
\text { satu suku kata }(20)\end{array}$ & $60 \%<\mathrm{P} \leq 100 \%$ & 14 & 16 & 11 & 70 & 80 & 55 \\
\hline 4 & $\begin{array}{l}\text { Membaca kata seder- } \\
\text { hana dari dua suku kata } \\
\text { (20) }\end{array}$ & $60 \%<\mathrm{P} \leq 100 \%$ & 12 & 14 & 11 & 60 & 70 & 55 \\
\hline
\end{tabular}

Nilai setelah dilakukan evaluasi melalui tes membaca kata, diperoleh data sebagai berikut.

Tabel 4. Nilai anak dari hasil evaluasi membaca siklus I

\begin{tabular}{cccc}
\hline No. & $\begin{array}{c}\text { Nama } \\
\text { Anak }\end{array}$ & Nilai & Keterangan \\
\hline 1. & PW & 7 & Tuntas \\
2. & FAR & 8,5 & Tuntas \\
3. & SDP & 6 & Belum Tuntas \\
Jumlah Nilai & 21,5 & \\
\multicolumn{2}{l}{ Rata - rata } & 7,16 & Tuntas \\
\hline
\end{tabular}

\section{e) Refleksi}

Setelah dilaksanakan tindakan pada siklus I, berdasarkan diskusi dengan kolaborator, perlu dilakukan tindakan pada siklus ke dua karena nilai anak belum mencapai indikator kinerja yang ditetapkan. Untuk itu pada tindakan berikutnya, perlu diusahakan agar kartu tidak digunakan anak untuk bermain saat pembelajaran sedang berlangsung. Caranya dengan menggunting kartu tidak per-gambar, melainkan beberapa gambar.

\section{Siklus II}

\section{a) Perencanaann}

Berdasarkan analisis setelah dilakukan siklus I, direncanakan tindakan untuk siklus II dengan kartu tidak dipotong per-gambar, melainkan dua gambar. Kartu superhero yang dipotong tiap dua gambar tersebut, akan ditulis kata sederhana. Kata yang ditulis merupakan gabungan vokal dan suku kata, atau suku kata dan suku kata lainnya. Pembelajaran direncanakan dalam 3 pertemuan pada akhir bulan September (22,23 dan 24 September 2014). Pertemuan pertama akan dilakukan kegiatan membaca kata sederhana dari dua suku kata. Pada pertemuan ke dua, akan dilakukan kegiatan membaca kalimat sederhana yang terdiri dari dua kata. Sedang pada pertemuan ke tiga akan dilkukan kegiatan membaca kalimat sederhana yang terdiri dari tiga kata.

\section{b) Pelaksanaan}

Setelah dilakukan percakapan guru mengambil kata yang menjadi topik percakapan. Menuliskan kata tersebut di papan tulis, lalu mengajak anak 
melakukan identifiasi. Selanjutnya guru menulis kata yang diidentifikasi pada punggung (sebalik) kartu superhero. Pertemuan pertama guru mengambil satu guntingan kartu superhero lalu menuliskan kata sederhana pada kartu yang merupakan gabungan dua suku kata. Anak diminta mengamati tulisan lalu diminta meniru ucapan guru. Selanjutnya anak diminta membaca kata sederhana mama, bumi, lupa, babi, pipa, bola, labu, lima, papi dan bima.

Pertemuan ke dua siklus 2, setelah membaca kata sederhana bola abi, ibu bobi, bibi ema, mama ali dan oma bima. Pertemuan ke tiga bola abi lima, ema ibu bobi, bibi ila lupa, oma ali mimi dan uli mama bima.

\section{c) Evaluasi}

Evaluasi dilakukan dengan meminta anak membaca kata dan kalimat sederhana dari kartu yang ditunjukkan guru. Pada saat evaluasi, guru melakukan pengamatan terhadap kemampuan anak dalam membaca dan membubuhkan cantangan pada lembar pengamatan yang sudah dipersiapkan oleh guru.

\section{d) Hasil Pengamatan}

Hasil pengamatan Anak merasa senang, karena setelah selesai membaca kalimat, anak diberi kesempatan melihat gambar superhero-nya. Hasil kemampuan mebaca kata dan kalimat sederhana, dapat dilihat pada tabel berikut.

Tabel 5. Hasil ketrampilan membaca setelah siklus 2

\begin{tabular}{|c|c|c|c|c|c|c|c|c|}
\hline \multirow{2}{*}{ No } & \multirow{2}{*}{$\begin{array}{c}\text { Variabel } \\
\text { Tindakan }\end{array}$} & \multirow{2}{*}{$\begin{array}{l}\text { Indikator yang } \\
\text { Ditetapkan }\end{array}$} & \multicolumn{3}{|c|}{$\begin{array}{l}\text { Penilaian aktifitas } \\
\text { siswa }\end{array}$} & \multicolumn{3}{|c|}{ Prosentase $(\%)$} \\
\hline & & & PW & FAR & SDP & PW & FAR & SDP \\
\hline 1 & $\begin{array}{l}\text { Membaca kata sederhana } \\
\text { (10) }\end{array}$ & $60 \%<\mathrm{P} \leq 100 \%$ & 8 & 9 & 7 & 80 & 90 & 70 \\
\hline 2 & $\begin{array}{l}\text { Membaca kalimat seder- } \\
\text { hana yang ter-diri dari } 2 \\
\text { kata sederhana (5) }\end{array}$ & $60 \%<\mathrm{P} \leq 100 \%$ & 4 & 5 & 3 & 80 & 100 & 60 \\
\hline 3 & $\begin{array}{l}\text { Membaca kaliamat seder- } \\
\text { hana yang ter-diri dari } 3 \\
\text { kata sederhana (5) }\end{array}$ & $60 \%<\mathrm{P} \leq 100 \%$ & 4 & 4 & 4 & 80 & 80 & 80 \\
\hline
\end{tabular}

Setelah dilakukan evaluasi melalui tes membaca kata, diperoleh data sebagai berikut.

Tabel 6. Nilai anak dari hasil evaluasi membaca siklus II

\begin{tabular}{lcccc}
\hline No. & $\begin{array}{c}\text { Nama } \\
\text { Anak }\end{array}$ & $\begin{array}{c}\text { Nilai } \\
\text { Siklus 1 }\end{array}$ & $\begin{array}{c}\text { Nilai } \\
\text { Siklus 1 }\end{array}$ & Keterangan \\
\hline 1. & PW & 7 & 8 & Tuntas \\
2. & FAR & 8,5 & 9 & Tuntas \\
3. & SDP & 6 & 7 & Tuntas \\
\multicolumn{2}{l}{ Jumlah Nilai } & 21,5 & 24 & Tuntas \\
\hline \multicolumn{2}{l}{ Rata - rata } & 7,16 & 8,00 & \\
\hline
\end{tabular}

\section{e) Refleksi}

Setelah dilakukan tindakan pada siklus 2, berdasarkan hasil pengamatan, ada peningkatan nilai pada semua anak. Pada PW ada peningkatan nilai dari 5 saat evaluasi awal (sebelum tindakan) menjadi 7 setelah siklus 1 dan meningkat menjadi 8 setelah tindaka siklus 2 .

Peningkatan nilai pada FAR dari nilai 7 pada evaluasi awal, menjadi menjadi 8,5 setelah siklus 1 dan meningkat menjadi 9 setelah siklus 2. Sedang SDP dari nilai 4 pada evaluasi awal menjadi 6 setelah siklus 1 dan meningkat menjadi 7 
setelah dilakukan tindakan pada siklus 2 .

Rata - rata nilai anak sudah mencapai nilai tuntas. Meskipun masih ada satu anak yang nilai pada kemampuan membaca kalimat sederhana dari dua kata berada pada batas minimal indikator keberhasilan yang ditetapkan $(60 \%<$ $\mathrm{P} \leq 100 \%$ ). Namun karena rata - rata nilai anak sudah 8 dengan prosentase keberhasilan $80 \%$, maka siklus kedua dianggap cukup.

\section{Pembahasan}

Deskripsi siklus I, anak mulai terbiasa dengan kegiatan membaca menggunakan kartu superhero. Kartu yang digunting dan diberi tulisan oleh guru sudah dipergunakan sebagai media belajar membaca. Kegiatan membaca pada siswa kelas satu sekolah dasar merupakan kegiatan membaanca permulaan, dimana anak diajak untuk mengenal simbolsimbol atau tulisan. Hal ini sejalan dengan apa yang disampaikan oleh Dalwadi tentang pengertian membaca permulaan, yaitu 'tahap dalam belajar membaca yang difokuskan kepada mengenal simbol-simbol atau tanda- tanda yang berkaitan dengan tulisan sehingga menjadi pondasi agar anak dapat melanjutkan ke tahap membaca lanjut.'

Awal pembelajaran, siswa terlihat antusias membaca vokal, kosa kata dan kata yang ditulis guru di sebalik kartu superhero. Anak merasa senang karena setelah berhasil membaca, anak diperbolehkan melihat gambar kartu superhero-nya.

Kegiatan pada siklus 1, masih berupa kegiatan merangsang siswa membaca kata lebih dulu. Dimulai dari membaca vokal, suku kata, kata sederhana yang merupakan gabungan vokal dan suku kata, dan kata gabungan dari dua suku kata. Hasil penelitian menunjukkan adanya peningkatan nilai pada semua anak. Dari data terlihat nilai rata - rata evaluasi membaca siswa sebelum tindakan sebesar 5,33, meningkat menjadi 7,16 setelah dilakukan tindakan siklus 1 . Hal ini berarti penggunaan kartu superhero dapat meningkatkan kemampuan membaca anak tunarungu.

Perbandingan kondisi awal dengan kondisi setelah siklus 1 dapat dilihat perubahannya dari diagram berikut.

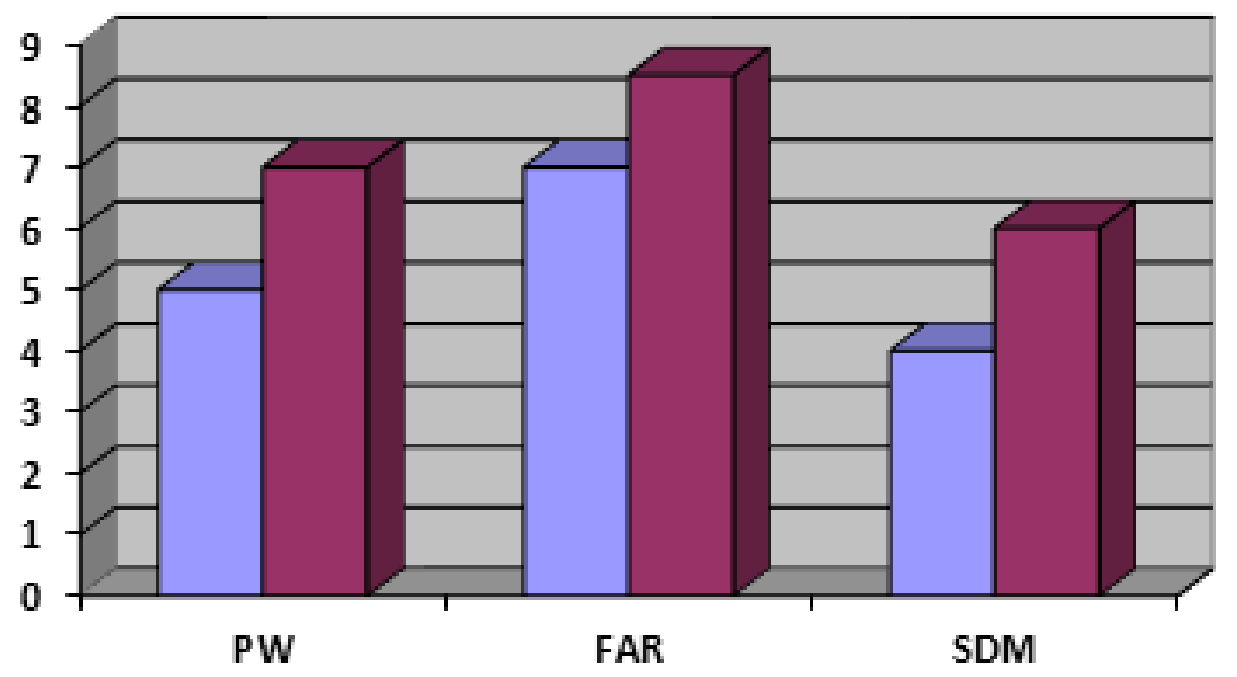

Diagram 1. Perbandingan nilai awal dan nilai setelah siklus 1

Hasil evaluasi setelah siklus 1 diperoleh nilai rata - rata 7,16 . Jika dikonsultasikan dengna indikator kinerja yang ditetapkan sebesar $(60 \%<\mathrm{P} \leq 100 \%)$, rata - rata nilai anak sudah berada pada rentang nilai $60 \%$ s.d $100 \%$, (tuntas). Namun karena masih ada siswa yang memperoleh nilai di bawah indikator yang ditetapkan, terutama untuk 
kompetensi membaca kata sederhana dari gabungan vokal dan suku kata, serta kata dari gabungan dua suku kata, maka perlu dilakukan tindakan pada siklus 2 .

Bedasarkan hasil refleksi siklus 1 perlu dilakukan siklus 2 dengan rencana kegiatan membaca kata dan kalimat sederhana. Tindakan dimulai dengan mengulang kembali kata sederhana yang sudah dibaca pada siklus 1, dilanjutkan dengan membaca kalimat sederhana. Hal ini dimaksudkan untuk memperbaiki kemampuan membaca kata yang sudah dilakukan pada siklus satu sekaligus melatih anak membaca gabungan kata yang dibentuk menjadi kalimat.

Setelah dilakukan siklus 2, terdapat peningkatan nilai kemampuan membaca terhadap semua siswa. Pada PW, ada peningkatan nilai dari 5 pada awal, menjadi 7 setelah siklus 1 dan 8 seelah siklus 2 . Pada FAR ada peningkatan nilai dari 7 pada awalnya, menjadi 8,5 setelah siklus 1 dan meningkat menjadi 9 setelah siklus 2 . Sedang pada SDM, juga terdapat peningkatan nilai dari 4 pada evaluasi awal, menjadi 6 setelah siklus 1 dan meningkat menjadi 7 setelah siklus 2. Hasil yang diperoleh tersebut, jika dikonsultasikan dengan indikator kinerja yang ditetapkan sebesar $60 \%<\mathrm{p} \leq 100$, maka dapat dikatakan bahwa tindakan yang dilakukan sudah berhasil mencapai indikator kinerja yang ditetapkan.

Perubahan setelah kegiatan siklus 2, jika dibandingkan dengan kondisi awal dan siklus 1, maka akan terlihat dari diagram berikut ini.

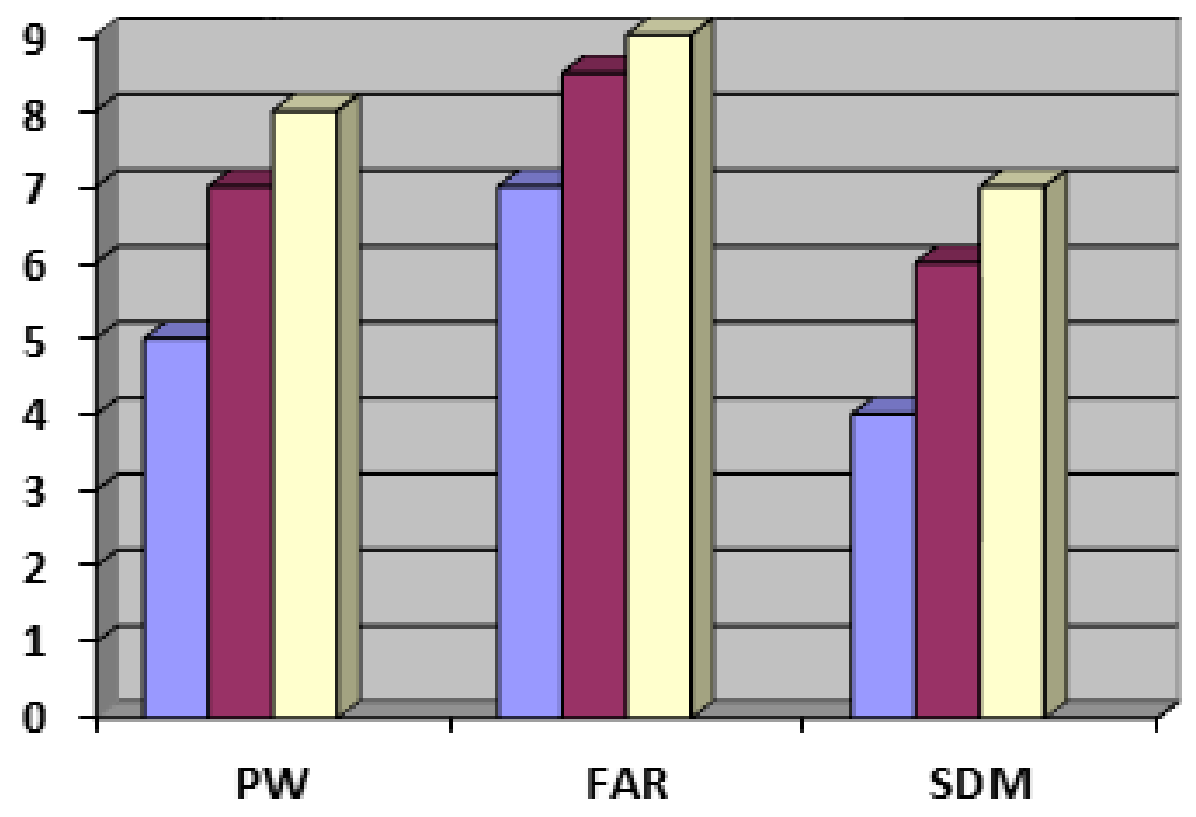

Diagram 2. Perbandingan nilai awal, nilai setelah siklus 1 dan nilai setelah siklus 2

Hasil diskusi dengan rekan, bahwa penggunaan kartu superhero ternyata dapat meningkatkan minat anak dalam belajar membaca. Kartu superhero yang digunting tiap dua gambar ternyata lebih efektif digunakan, karena disamping anak tidak dapat menggunakannya untuk bermain, anak merasa dapat melihat gambar tokoh superhero dalam urutan. Karena hasil tindakan sudah mencapai indikator yang ditetapkan maka tindakan dirasa cukup.

Peningkatan Kompetensi dari hasil evaluasi setiap akhir siklus. Peningkatan kemampuan membaca pada anak tunarungu 
kelas 1 SLB B YPALB Karanganyar dapat dilihat dari hasil evaluasi pada akhir setiap siklus. Peningkatan kompetensi membaca siswa yang dicapai pada penelitian ini dapat dilihat dari diagram berikut.

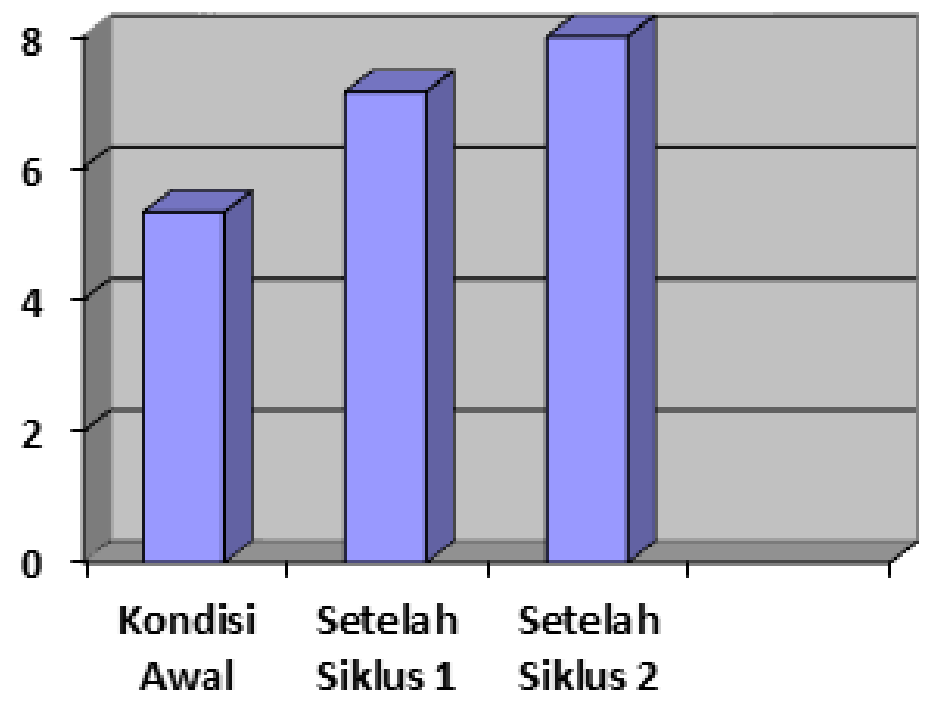

$\square$ Nilai Rata rata

Diagram 3. Grafik peningkatan kompetensi membaca dengan menggunakan kartu superhero

Peningkatan ketrampilan siswa dalam membaca setelah dilakukan tindakan dalam dua siklus ini, seperti yang penah dilakukan oleh Nur Farikatul Fitriyah (2009) tentang penggunaan media kartu huruf dan kartu kata pada siswa kelas 1 SDN 01 Sudimoro menunjukkan bahwa ada peningkatan aktifitas belajar dan hasil belajar siswa. Pada siklus I hasil belajar hasil belajar siswa menunjukkan rata - rata 70,91 dan pada siklus II meningkat menjadi 83,91. Ketuntasan belajar yang pada siklus I masih $68,18 \%$, pada siklus II meningkat menjadi 95,50\%.

\section{Simpulan}

Simpulan dari penelitian ini, kartu superhero ternyata dapat dijadikan media pembelajaran membaca. Pembelajaran dilakukan dengan menggunting kartu superhero pada tiap-tiap gambar. Kemudian memberi tulisan di sebalik kartu tersebut.

Sebelum membaca, dilakukan percakapan, lalu dipilih vokal, suku kata maupun kata dan kalimat yang akan dijadikan bahan latihan membaca. Tindakan pada siklus 1 dimulai dengan membaca vocal, suku kata dan kata. Kegiatan dilakukan dengan menulis di sebalik kartu superhero yang digunting per gambar, lalu anak diminta membaca. Selama anak membaca, guru mengamati sambil memberi centangan instrument yang sudah disiapkan guru.

Kegiatan pada siklus 2, juga dilakukan dengan menulis kata atau kalimat di sebalik kartu superhero. Jika pada siklus 1 gambar digunting per gambar, pada siklus 2 gambar digunting tiap dua gambar. Tindakan dimulai dari membaca kata, kalimat dari dua kata dan kalimat dari tiga kata.

Berdasarkan hasil penelitian disimpulkan bahwa, kartu penggunaan kartu superhero dapat meningkatkan kemampuan membaca pada anak tunarungu. Sebelum dilakukan tindakan, rata-rata nilai kemapuan membaca anak, 5,33 atau berada pada rentang $40 \%<\mathrm{P} \leq$ $60 \%$ atau cukup. Setelah dilakukan tindakan siklus 1, rata-rata nilai anak meningkat menjadi 7,16 atau berada pada rentang $60 \%$ $<\mathrm{P} \leq 80 \%$ atau baik. Namun masih ada anak yang memperoleh nilai kurang dari 6 pada kompetensi membaca kata, sehingga perlu dilakukan tindakan siklus 2. Setelah 
dilakukan tindakan siklus 2 rata - rata nilai anak meningkat menjadi 8 atau berada pada rentang $60 \%<\mathrm{P} \leq 100 \%$ atau tinggi, tidak ada yang memperoleh nilai kurang dari 6 .

Saran 1) kepala sekolah, agar bijaksana dalam menyempaikan masukan pada guru terkait strategi pembelajaran membaca. 2). guru, pembelajaran Bahasa Indonesia hendaknya dilakukan dalam suasana yang menyenangkan. Salah satunya melalui kegiatan membaca dengan media kartu superhero. 3). orang tua, agar meluangkan waktunya untuk mendampingi anak bermain dan menggunakan kesempatan bermain tersebut untuk meningkatkan kemampuan membaca.

\section{Daftar pustaka}

DP. Tampubolon. 2008. Kemampuan Membaca. Teknik Membaca Efektif dan Efisien. Bandung:Angkasa

Dalwadi. 2002. Pengaruh Penerapan Metode SAS Terhadap Kemampuan Membaca Permulaan Bagi Anak Tunagrahita Ringan. Skripsi S1 Pada Jurusan PLB FIP UPI Bandung: tidak diterbitkan.

Iqmal. 2010. Superhero. Iqmal.staff.ugm.ac.id/index.php/, diakses 5 Agustus 2010

Lani Bunawan dan Maria Cecilia SY. 2000. Penguasaan Bahasa Anak Tunarungu. Jakarta:Yayasan Santi Rama

Mufti Salim.1984. Pendidikan Anak tunarungu. Jakarta:Depdikbud

Nur Farikatul Fitriyah. 2009. Penggunaan Media Kartu Huruf dan Kartu Kata pada Ssiswa Kelas 1 SDN 01 Sudimoro. Jurnal Penelitian. Diakses tanggal 3 Agustus 2010

Suharsimi Arikunto. 2003. Prosedur Penelitian Suatu Pendekatan Praktek. Jakarta:Rineka Cipta

Susilo. 2007. Panduan Penelitian Tindakan kelas. Yogyakarta:Pustaka book publisher.

Sutama, 2010. Metode Penelitian Pendidikan Kuantitatif, Kualitatif. PTK, $R \&$ D, Surakarta, Fairuz Media.

Sutama, 2014. Penelitian Tindakan : PTK, PTS dan PTBK. Surakarta : Fairus Media 'Duta Permata Ilmu".

Wahab, R. 2003. Diktat Mengenal Anak Berkelainan. Yogyakarta: PLB/FIP/IKIP Yogyakarta. 